\title{
Current Status and Trend Analysis of China's Import Cross-border E-commerce Development
}

\author{
Zhenhua Yang ${ }^{1, \text { a }}$, Qiang Shen ${ }^{2, b}$ \\ ${ }^{1}$ Jiangxi Normal University of Science and Technology, china \\ ${ }^{2}$ Nanchang University, china \\ aemail: yzh340@126.com, bemail: 414801271@qq.com
}

\begin{abstract}
Keywords: Import cross-border e-commerce, Cross-border logistics, Cross-border e-commerce supervision.
\end{abstract}

\begin{abstract}
The import cross-border e-commerce as a new industry has achieved rapid development in China. Besides, it has become a new growth point of China's e-commerce market and new "Blue Ocean" of the e-commerce industry. In China, on the trade scale and business mode maturity, the import e-commerce has great difference from the export e-commerce. Moreover, there are restraining factors in the customs clearance efficiency, e-payment, etc. Based on analyzing the above problems, this paper discusses the suggestions on promoting the sound development and analyzes the future trend, with the purpose of providing reference for the further development of the import cross-border e-commerce.
\end{abstract}

\section{Introduction}

Since 2013, China's import cross-border e-commerce has achieved rapid development under the promotion of the market, media and capital, and it also has become a new "blue ocean" of the e-commerce industry. The foreign famous brands are popular with the domestic consumers all along, and the import cross-border e-commerce business also has sprung up. At the beginning, the domestic consumers generally purchased the famous European and American brands with great price difference in China. However, with the constant increasing of the overseas shoppers and the constant evolution of the e-commerce environment, the consumers' targets has already been shifted to the small and medium overseas brand commodities with greater scope, more suitable for the mass. Most of those commodities belong to fair-price goods. In most cross-border e-commerce platform, there are so many deals on the clothes and cosmetics of South Korea and other countries every day. Lots of overseas brands already get much closer and even surpass their mainstream marketing channels in our domestic online shopping channel. The rapid development of the import cross-border e-commerce has optimized the international resource allocation, enriched the shopping selection of the domestic consumers, and brought positive competitiveness environment for other domestic importers. However, there are many restriction factors in China's import e-commerce development. Apart from the law environment and consumers' habits, they mainly get involved in the cross-border logistics, payment, clearance, and other basic links. With the implementation of the urban planning of China's cross-border trade e-commerce service experiment units, the corresponding basic data and experience will be gradually accumulated, which is favorable for promoting the further increasing of deals in China's cross-border trade markets.

\section{Current status of the import cross-border e-commerce development}

Overall trade volume of the import cross-border e-commerce. According to Table 1, China's e-commerce reached RMB 4,000 billion of market scale in 2014, while China's import e-commerce trade scale was only RMB 530 billion, which was almost the change of the whole China's e-commerce trade, accounting for quite low proportion among the cross-border e-commerce. However, from the data of Table 1, it can be calculated that the market compound annual growth rate (CAGR) of the import cross-border e-commerce from 2011 to 2014 reached 61.4\%, which was 
much higher than 32.4\% CAGR of the cross-border e-commerce and 21.2\% CAGR of the whole e-commerce industry. It indicates that the market penetration rate and market scale of the import e-commerce will achieve rapid promotion and expansion in the future years. The statistical data of IResarch indicates that, China's import e-commerce is predicted to keep the average growth rate of $34 \%$ from 2015 to 2017, which will far exceed the average growth rate of $16 \%$ of the cross-border e-commerce.

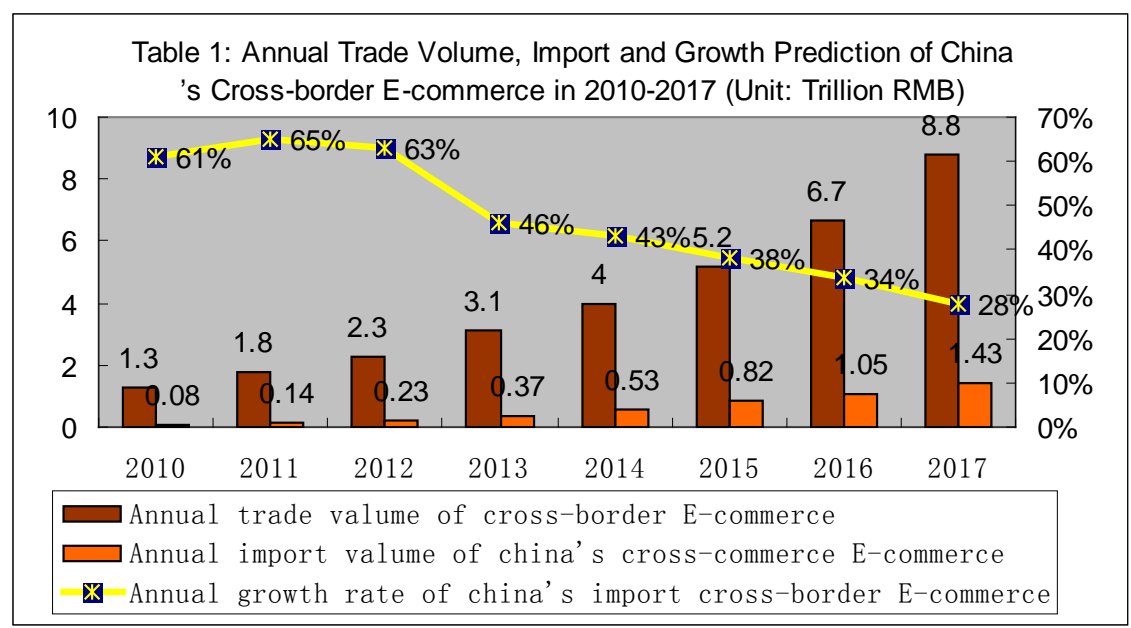

Data source: obtained from the data of State Statistics Bureau and calculated from IResearch Statistics Model

In addition, from the import and export structure of China's cross-border e-commerce in Table 2, it shows that the proportion of China's export cross-borer e-commerce in 2014 reached 86.7\%, while the import proportion was $13.3 \%$. It indicates that, although China's cross-border e-commerce achieved rapid development, it was still in the starting phase. With the increasing demands for the overseas commodities in China, it is predicted that, in the future years, although the cross-border e-commerce will be affected by the national polices, the share proportion of China's import cross-border e-commerce will still keep the rapid promotion.

Table 2 Import and Export Proportion Structure and Predication Table of China's Cross-border E-commerce from 2010 to 2017

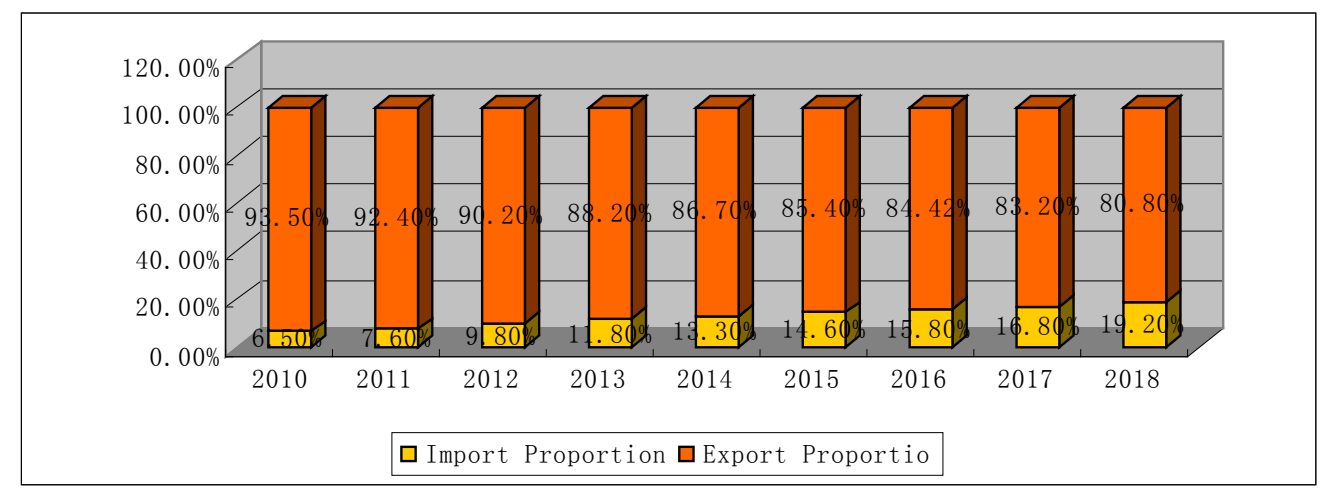

Import cross-border e-commerce modes. According to different business forms, its status and effect in the trade circulation link, and different commercial modes, the import cross-border e-commerce market is divided into five categories: B2B platform, C2C platform, B2C platform, flash sales platform, shopping guide and rebate platform. B2C platform also can be divided into three small categories: the third-party B2C platform, comprehensive self-support B2C platform, and vertical self-sport B2C platform. Therefore, the whole import cross-border e-commerce can be divided into seven small categories. Different modes have different operating ways, so that the advantages and disadvantages they present are also different, which is shown in Fig. 1. 
Fig. 1 Summary and Analysis Sheet of China's Import E-commerce Platform Modes

\begin{tabular}{|c|c|c|c|c|}
\hline $\begin{array}{l}\text { Platform } \\
\text { modes }\end{array}$ & $\begin{array}{c}\text { Representative } \\
\text { enterprise }\end{array}$ & Operating way & Advantage & Disadvantage \\
\hline B2B platform & $\begin{array}{l}\text { International } \\
\text { Website of } \\
\text { Alibaba }\end{array}$ & $\begin{array}{l}\text { Integration of } \\
\text { online platform and } \\
\text { offline trade }\end{array}$ & $\begin{array}{l}\text { Abundant products, } \\
\text { provide supply and } \\
\text { demand information, } \\
\text { enquiry, payment, } \\
\text { etc. } \\
\end{array}$ & $\begin{array}{l}\text { The logistics and customs } \\
\text { clearance is done according } \\
\text { to the traditional way, with } \\
\text { low efficiency and long time } \\
\text { consuming. }\end{array}$ \\
\hline C2C platform & $\begin{array}{c}\text { Global Purchase } \\
\text { of Taobao }\end{array}$ & $\begin{array}{l}\text { Overseas } \\
\text { purchasing } \\
\text { platform }\end{array}$ & $\begin{array}{l}\text { Abundant products, } \\
\text { big user flow, low } \\
\text { access threshold of } \\
\text { the merchant }\end{array}$ & $\begin{array}{l}\text { Weak control on the supply } \\
\text { chain; false or artificial goods } \\
\text { may exist; slow logistics }\end{array}$ \\
\hline $\begin{array}{l}\text { The third-party } \\
\text { B2C platform }\end{array}$ & $\begin{array}{c}\text { Tmall } \\
\text { International }\end{array}$ & $\begin{array}{l}\text { Foreign wholesaler } \\
\text { or manufacturer' s } \\
\text { direct delivery, } \\
\text { direct shipment } \\
\text { platform }\end{array}$ & $\begin{array}{l}\text { Strong control on the } \\
\text { supply chain; genuine } \\
\text { product; fast logistics }\end{array}$ & $\begin{array}{l}\text { Slow investment attraction in } \\
\text { early phase; great capital } \\
\text { demand; limited product } \\
\text { variety; small use flow }\end{array}$ \\
\hline $\begin{array}{l}\text { Comprehensive } \\
\text { self-support } \\
\text { B2C platform }\end{array}$ & No.1 Higo & $\begin{array}{l}\text { Suppliers establish } \\
\text { the cross-border } \\
\text { self-support } \\
\text { platform }\end{array}$ & $\begin{array}{l}\text { Strong control on } \\
\text { supply chain; the } \\
\text { quality is guaranteed; } \\
\text { sufficient capital; fast } \\
\text { logistics }\end{array}$ & $\begin{array}{l}\text { Greatly restricted by the } \\
\text { industry policy }\end{array}$ \\
\hline $\begin{array}{l}\text { Vertical } \\
\text { self-sport B2C } \\
\text { platform }\end{array}$ & Miyabaobei.com & $\begin{array}{c}\text { Vertical } \\
\text { self-support } \\
\text { platform for } \\
\text { specific product } \\
\text { supplier }\end{array}$ & $\begin{array}{l}\text { Strong control on the } \\
\text { supply chain; genuine } \\
\text { brand; fast logistics }\end{array}$ & $\begin{array}{l}\text { Great capital demand; limited } \\
\text { to the specific products; small } \\
\text { user flow }\end{array}$ \\
\hline
\end{tabular}

Data source: obtained from the report about the import retail e-commerce industry

Main problems in the import cross-border e-commerce. Customs clearance problem. At present, the greatest bottleneck the cross-border e-commerce logistics is the customs clearance problem. In general, B2B clearance mode adopts the traditional mode. Therefore, it is quite time-consuming. The cross-border e-commerce import " $5+1$ " experiment unit in 2013 is not applicable to this mode. The clearance time of the cross-border B2C and cross0border C2C can be controlled in 2 days. However, the current biggest problem lies in that most cross-border B2C and B2B2C cannot meet the requirements of "the integration of logistics, capital flow and information flow" of General Administration of Customs, and it only can adopt the general mode for the customs clearance. Shen Yeceng, CTO of Sintrans E-commerce Co., Ltd, presented that, "With regard to the product delivered from Los Angeles to Shanghai, if the flight of the airline is adopted, the delivery time will not exceed 22 hours even though the goods picking and delivery time are included. The domestic distribution adopts SF-Express. The total time will not more than 3 days. However, the general time of the current cross-border e-commerce logistics is about 20 days. That is to say, it takes 19 days for the customs clearance of most commodities, which absolutely cannot meet the customers' requirements on the convenience and rapidness.”

Logistics problem. The information flow, currency flow and commodity flow in the import process of the cross-border e-commerce are realized through the virtual network. Only the logistics is fulfilled off line. These four procedures must be smooth, so that the speed and efficiency of the cross-border import can reach the best effect. Although China's import cross-border e-commerce has achieved rapid development, there is still some deficiency in the cross-border import logistics. The import cross-border e-commerce logistics is mainly divided into two kinds. One kind is B2B. The problem that is urgent to be solved is the supply chain response based on the logistics, such as selection of import agents, application for import licensing, selection of sea transportation routine, research on the lowest shipping cost, establishment of transnational informationization management platform, etc. However, B2C and C2C mainly solve the problems about too long transportation time, high cost, and difficulty in tracking.

Payment problem. At present, the import payment of China's cross-border e-commerce mainly has three modes: payment done through the third-party platform, direct payment through e-bank, and direct international clearing of RMB. From Fig.2, it can be seen that the third-party payment 
has already become a major payment way of the import cross-border e-commerce. To adapt to the rapid development of the cross-border import trade, it is necessary to support and encourage the development of the cross-border third-party institute. However, there are some problems in using the cross-border third-party payment. Firstly, the country stipulates that, if the cross-border single trade volume exceeds USD30,000, it is necessary to submit tax administration voucher. Without such regulation, the National Tax Bureau cannot present related vouchers. Therefore, if the single remittance of the third-party payment enterprise exceeds USD30,000, the payment cannot be done. Secondly, the legal supervision and management has vacuum zone. Before the third-party payment institution does not achieve the cross-border payment qualification, it can cooperate with the foreign banks and payment institutions, and realize the cross-border payment through sharing the account, which avoids the supervision and management from the third-party enterprise and provides possibility for encroaching on the users' rights and interests.

Fig.2 Main operation modes of the domestic and foreign cross-border payment enterprises

\begin{tabular}{|c|c|c|c|c|c|c|c|}
\hline Type & $\begin{array}{l}\text { Enter } \\
\text { prise } \\
\text { name }\end{array}$ & $\begin{array}{l}\text { Service/ } \\
\text { Product }\end{array}$ & $\begin{array}{l}\text { Service } \\
\text { type }\end{array}$ & Service object & $\begin{array}{c}\text { Payment } \\
\text { card/Currency }\end{array}$ & $\begin{array}{l}\text { Settlem } \\
\text { ent } \\
\text { currency }\end{array}$ & $\begin{array}{l}\text { Coverage } \\
\text { area }\end{array}$ \\
\hline $\begin{array}{c}\text { Domestic } \\
\text { third-party } \\
\text { payment }\end{array}$ & Alipay & $\begin{array}{l}\text { Overseas } \\
\text { purchase }\end{array}$ & $\begin{array}{l}\text { Cross-border } \\
\text { purchase }\end{array}$ & Alipay member & RMB & $\begin{array}{l}\text { Foreign } \\
\text { currency }\end{array}$ & $\begin{array}{c}\text { Hong Kong, } \\
\text { Macao, Taiwan, } \\
\text { Japan, South } \\
\text { Korea, Australia, } \\
\text { U.K, America, } \\
\text { Italy }\end{array}$ \\
\hline $\begin{array}{c}\text { Domestic } \\
\text { third-party } \\
\text { payment }\end{array}$ & $\begin{array}{l}\text { Quick } \\
\text { money }\end{array}$ & $\begin{array}{l}\text { Internatio } \\
\text { nal } \\
\text { exchange } \\
\text { collection }\end{array}$ & $\begin{array}{l}\text { Cross-border } \\
\text { purchase, } \\
\text { foreign trade } \\
\text { B2B }\end{array}$ & $\begin{array}{c}\text { Foreign } \\
\text { enterprise } \\
\text { required to } \\
\text { explore the } \\
\text { international } \\
\text { business }\end{array}$ & $\begin{array}{l}\text { Express, JCB and } \\
\text { other } \\
\text { international } \\
\text { cards, PayPal } \\
\text { accounts }\end{array}$ & RMB & $\begin{array}{l}\text { Over } 190 \\
\text { countries and } \\
\text { regions over the } \\
\text { world }\end{array}$ \\
\hline $\begin{array}{c}\text { Overseas } \\
\text { third-party } \\
\text { payment }\end{array}$ & PayPal & $\begin{array}{l}\text { No } \\
\text { boundary } \\
\text { purchase, } \\
\text { foreign } \\
\text { trade }\end{array}$ & $\begin{array}{l}\text { Cross-border } \\
\text { purchase, } \\
\text { international } \\
\text { card service, } \\
\text { international } \\
\text { trade }\end{array}$ & $\begin{array}{l}\text { eBay buyer and } \\
\text { seller, users of } \\
\text { the bank card } \\
\text { that PayPal } \\
\text { cooperates with }\end{array}$ & $\begin{array}{c}\text { Cards of } \\
15,000 \text { banks } \\
\text { over the world, } \\
\text { credit card, } \\
\text { PayPal account }\end{array}$ & $\begin{array}{l}\text { Currency } \\
\text { of the } \\
\text { region } \\
\text { where the } \\
\text { merchant } \\
\text { stays }\end{array}$ & $\begin{array}{l}\text { Over } 190 \\
\text { countries and } \\
\text { regions over the } \\
\text { world }\end{array}$ \\
\hline
\end{tabular}

Data source: obtained from the report about the import e-commerce industry

\section{Suggestions and trend analysis on the import cross-border e-commerce development}

Suggestions on the import cross-border e-commerce development. To achieve further development for the cross-border e-commerce, it is necessary to effectively solve problems it faces during the development.

Customs clearance problem. To improve the customs supervision and management mode, as the the import cross-border e-commerce has the feature of rapidness and small lot, the supervision of the customs on it should meet its feature. To improve the science and technology supervision level, the customs should carry out "full-course electronic clearance" and "summarizing customs clearance acceptance and permission" modes, optimize the supervision procedure, cancel the intermediate link, improve the customs clearance efficiency to the greatest extent, actively carry out import cross-border e-commerce " $5+1$ " experiment unit, combine the free trade area with the tariff-free zone, and form new logistics storage mode. The cross-border e-commerce enterprise can prepare goods in the free trade area and tariff-free zone, and deal with the customs clearance rapidly through the cross-border e-commerce of the customs according to the order requirements of the consumers. It saves more time for the customers to receive the goods, compared with the process of collecting goods at abroad, delivering them to China, and then going through customs clearance.

Logistics problem. B2B cross-border import logistics can be solved through certain policy encouragement and cultivating enterprises that are familiar with and proficient in the cross-border supply chain management, and have great cross-border logistics force. The Sinotrans development 
and 4PX also have got involved, and achieved certain results. But, it is far from the target of low price and high-efficiency solution. It is feasible to solve this problem through the alliance or business expansion based on some enterprises. In addition, with regard to cross-border B2C and C2C, the buyer can establish overseas warehouses in China, make use of the line logistics distribution channels set by the cross-border e-commerce platform, and formulate specific logistics routines, so as to solve the problems about high cost and long time.

Payment problem. It is necessary to standardize and support the development of the third-party payment platform, support the domestic third-party payment platform, carry out the import cross-border payment service, encourage the cooperation between the e-commerce platform and international third-party payment platform, so as to make the import cross-border become more mature on the payment mode. Meanwhile, it is important to establish self-discipline mechanism for the third-party payment enterprise, strengthen the supervision on the third-party cross-border payment, and abide by laws.

Trend analysis on the import cross-border e-commerce development. Firstly, the product variety and target market are diversified. At the beginning, the import cross-border e-commerce was focused on the European and American luxurious articles. Till now, the product variety has been greatly expanded, including costumes, cosmetics, jewelry, electronics, watches, food, medicine, computer, accessories, auto spare parts, small household appliances, and even home appliances, vehicle and other large products. Except for the target markets in America, Hong Kong, Japan, U.K, Australia, and other countries with relatively mature online shopping, it is expanded to Russia, Brazil, India, Southeast Asia and other emerging online shopping markets. With the further development of the global e-commerce, the variety of the cross-border e-commerce will be expanded, while the Central and Eastern European and Latin American markets with low electronics penetration rate will get breakthrough in the future.

Secondly, the proportion of the import cross-border B2C will be improved. It has the following obvious advantages. (a) It has large profit margin. Compared with the traditional mode, it can skip through all intermediate links and realize the shortest channel, and then obtain the maximal profit. (b) It can well grasp the market demands. To face the consumers directly, it can well master the market demands, and provide personalized customization for the customers. (c) The market is vast. Compared with the traditional foreign trade, B2C is not restricted by the territory, and it can face to over 200 countries, and reduce the competitiveness pressure.

Thirdly, "digitalization" refers that, with the deep application of the information network technology, the category and trade volume of the digitalized products (e.g. software, film and television, game, etc.) has achieved rapid growth. Besides, the trend of marketing and consuming through the import cross-border e-commerce has become more and more obvious. By contrast, the traditional international trade mainly exists in the physical product or service.

\section{References}

[1] Jiusan Society, Beijing Committee. Focus on Cross-border E-commerce Development. Beijing Observation,( 2012)11.

[2] Q. Chen, K.S. Lin. Primary Investigation on Cross-border Development of the Third-party Payment Enterprise. Special Zone Economy(2013)09.

[3] S.Y. Cao and Z.X. Li. Research on the Third-Party Logistics Mode of Cross-border E-commerce. E-commerce.(2013)03.

[4] X.J. Yin. Analysis on International Development Problems of China's Third-party Payment. China Business \& Trade.( 2012) 09.

[5] Y.X. Wang. Analysis on B2C Cross-border E-commerce Logistics Countermeasures of E-commerce Enterprises. Electronic Production. (2013)06. 